\title{
The Outcome of Surgical Excision of Giant Supratentorial Brain Tumors in Pediatrics: A Study of Consecutive 70 Cases at our Institute
}

\author{
AHMED H. ASHRY, M.D.; AYMAN TAREK MAHMOUD, M.D. and HASHEM M. ABOUL-ELA, M.D. \\ The Department of Neurosurgery, Faculty of Medicine, Cairo University
}

\begin{abstract}
Background: Surgery of giant supratentorial pediatric brain tumors (GSPBT) is challenging. Diagnosis may be misled by the inconspicuous symptoms and signs. Surgery is difficult due to the propensity for severe hemorrhage which is risky in this age group.
\end{abstract}

Aim of Study: We discuss the surgical management of GSPBT with emphasis on how to reach maximal safe resection and different surgical strategies to improve the outcome.

Patients and Methods: All Patients with GSPBT undergoing elective surgery were included of age 3 months to 12 years. Giant tumors were defined by being larger than $5 \mathrm{~cm}$. General anesthesia was performed by neuroanesthesiologists. Various tools and instruments were used such as Cavitating ultrasonic aspirator, microscope and endoscope. Blood transfusion was performed as early as possible to replace losses. Extent of removal was assessed from CT or MRI scans.

Results: This study included 70 children operated for GSPBT. There were 47 males (67.1\%) and 23 females (32.9\%). The age ranged from 3 to 144 months with a mean age of 56.3 months. The commonest presenting symptoms were those of raised intracranial pressure (ICP) in 61 cases $(87.1 \%)$. Gross total resection was achieved in 57 patients $(81.4 \%)$, debulking up to $80 \%$ in 3 patients $(4.3 \%)$, debulking up to $50 \%$ in 1 patient $(1.3 \%)$ and partial resection less than $50 \%$ in 9 patients (12.9\%). The amount of blood transfusion ranged from 5 to $300 \mathrm{ml} / \mathrm{kg}$ with a mean amount of $39.4 \mathrm{ml} / \mathrm{kg}$. PNET was the most common pathological diagnosis. Two cases required interruption of the procedure due to massive bleeding causing hypotension $(2.9 \%)$. There were no complications due to massive blood transfusion. There were no cases of mortality.

Conclusion: GSPBT can be totally resected with a good outcome. This needs a team approach including a good anesthesia team and proper postoperative care. Surgical techniques including sub-pial technique, endo scope- assisted microsurgery, and the CUSA may help accomplish this target.

Key Words: Giant-Supratentorial-Pediatric-Brain tumors - Surgery.

Correspondence to: Dr. Ahmed H. Ashry, The Department of Neurosurgery, Faculty of Medicine, Cairo University

\section{Introduction}

SURGERY of giant supratentorial brain tumors in children is quite a challenge. They are defined as "Giant" by being larger than $5 \mathrm{~cm}$ in any dimension [1]. Usually, these children present with nonspecific symptoms and signs which may delay diagnosis leading to overgrowth of the tumor. These patients are susceptible to various operative complications such as bleeding in addition to postoperative complications. Infants are vulnerable to hypothermia which may manifest by bradycardia and delayed recovery from anesthesia [2]

Most of GSPBT are malignant. Surgery is the gold standard [3]. Radiotherapy is better avoided below the age of 4 years as it is known to cause delayed complications in this age group [4]. Neoadjuvant chemotherapy may be used instead however it is linked to several complications in children including risk of bleeding in the tumor, blood dyscrasias, and may cause increased ICP leading to neurological deterioration [5]

In this study we present our experience in management of GSPBT in 70 children. To attempt total excision in these cases was widely regarded dangerous. However, with the incorporation of multidisciplinary team approach of neurosurgeons, anesthesiologist, intensivists, and pediatricians may help in such endeavor. We employed various strategies which we believe may improve the outcome.

\section{Patients and Methods}

After approval from the Institutional Review Board, this study was conducted retrospectively at Cairo University Hospitals during the period between 2016 till 2019. We studied all cases of giant supratentorial tumors in the pediatric age group from 3 months to 12 years who were operated 
electively. Giant tumors were defined as those exceeding $5 \mathrm{~cm}$ in size. All patients were subjected to complete history taking and clinical examination. Routine laboratory blood tests were performed. MRI brain with IV Gadolinium contrast was obtained in addition to CT scans. Antiepileptic medication IV was administered as a loading dose according to the body weight preceding surgery.

General Anesthesia was conducted by anesthesiologists specialized in pediatric neurosurgical anesthesia. Tumors were approached through a large craniotomy according to their site for better exposure and to control the elevated ICP due to brain edema. Various utilities in the operating room were used including operative microscope, endoscope, Cavitating Ultrasonic aspirator (CUSA), warm-air blower and heated mattress. Total excision was attempted in all cases with the help of bipolar coagulation, suction and CUSA. Estimation of blood loss was continuously monitored by the anesthesiologist. Units of matched Packed RBCS were made readily available and compensation of blood loss was initiated as early as possible. Hemostasis was achieved using absorbable gelatin sponge (Gelfoam) and absorbable hemostatic oxidized cellulose polymer (Surgicel). Watertight dural closure was ensured in every case. Closure in layers was carried out with subgaleal drain placement. Patients were admitted to the intensive care unit. Immediate Postoperative CT scans were

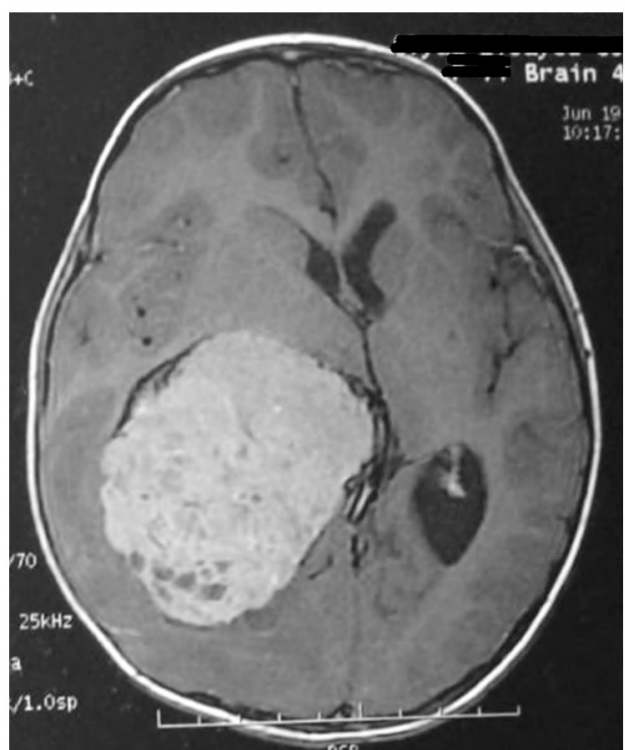

(A) performed within 12 hours to detect the presence of complications requiring reoperation such as hematomas, hydrocephalus or large residual. Assessment of the extent of removal was made from postoperative CT scans or MRI scans performed during the hospital stay.

\section{Results}

This study was conducted on 70 children operated for GSPBT. There were 47 males $(67.1 \%)$ and 23 females $(32.9 \%)$. The age ranged from 3 to 144 months with a mean age of 56.3 months. The commonest presenting symptoms were those of raised intracranial pressure (ICP) in 61 cases (87.1\%). Twenty cases presented with seizures (28.6\%), 17 cases presented with hemiparesis (24.3 $\%$ ), and 3 cases presented with diminution of vision. The site of the tumor is shown in (Table 1). Gross total resection was achieved in 57 patients $(81.4 \%)$ (shown in Fig. 1), debulking up to 80\% in 3 patients (4.3\%), debulking up to $50 \%$ in 1 patient $(1.3 \%)$ and partial resection less than $50 \%$ in 9 patients $(12.9 \%)$. The amount of blood transfusion ranged from 5 to $300 \mathrm{ml} / \mathrm{kg}$ with a mean amount of $39.4 \mathrm{ml} /$ $\mathrm{kg}$. The histopathology of the tumors is shown in (Table 2). PNET was the most common type. Complications are shown in (Table 3). Two cases required interruption of the procedure due to massive bleeding causing hypotension (2.9\%). There were no complications due to massive blood transfusion. There were no cases of mortality.

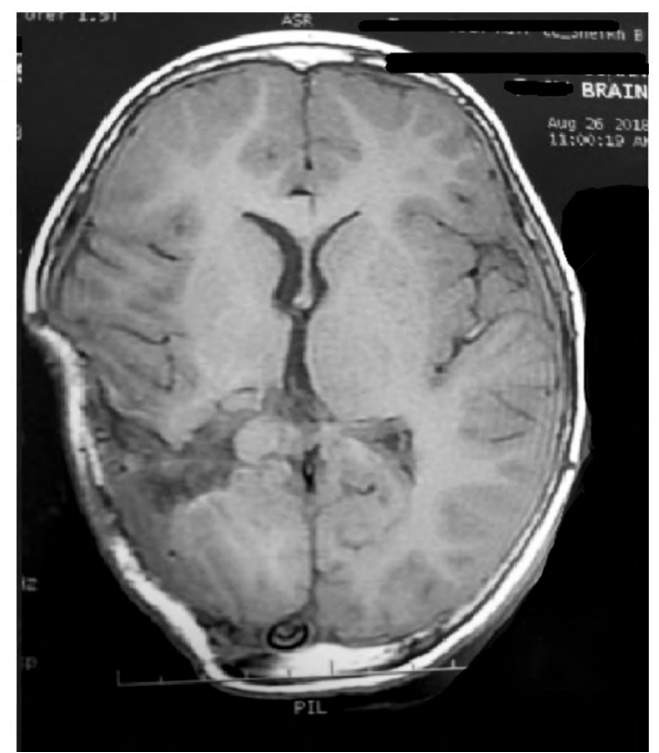

(B)

Fig. (1): A 7-year-old female child presenting with headache. MRI brain with contrast showed a giant intraventricular tumor (A). It was approached surgically through a parietal corticectomy. The superficial part of the tumor was invasive and was dealt with through a sub-pial plane. After devascularization of the tumor, the rest of the tumor was excised using the CUSA. Gross total resection was achieved as shown in (B) with good recovery and outcome. 
Table (1): Location of the tumor.

\begin{tabular}{|c|c|c|c|}
\hline & Rt. F P & \multicolumn{2}{|c|}{$11(15.7 \%)$} \\
\hline & Rt. F & \multicolumn{2}{|l|}{$6(8.6 \%)$} \\
\hline & Lt. F IVT & \multicolumn{2}{|l|}{$5(7.1 \%)$} \\
\hline & Lt. F P & \multicolumn{2}{|l|}{$5(7.1 \%)$} \\
\hline & Lt. F & \multicolumn{2}{|l|}{$4(5.7 \%)$} \\
\hline & Lt. T & \multicolumn{2}{|l|}{$4(5.7 \%)$} \\
\hline & Rt. T & \multicolumn{2}{|l|}{$4(5.7 \%)$} \\
\hline & Lt. P & \multicolumn{2}{|l|}{$3(4.3 \%)$} \\
\hline & Lt. P O & \multicolumn{2}{|l|}{$3(4.3 \%)$} \\
\hline & Lt. T P IVT & \multicolumn{2}{|l|}{$3(4.3 \%)$} \\
\hline & Suprasellar & \multicolumn{2}{|l|}{$3(4.3 \%)$} \\
\hline & Rt. F IVT & \multicolumn{2}{|l|}{$2(2.9 \%)$} \\
\hline & Rt. F P T & \multicolumn{2}{|l|}{$2(2.9 \%)$} \\
\hline & Rt. O & \multicolumn{2}{|l|}{$2(2.9 \%)$} \\
\hline & Rt. P & \multicolumn{2}{|l|}{$2(2.9 \%)$} \\
\hline & Rt. P O IVT & \multicolumn{2}{|l|}{$2(2.9 \%)$} \\
\hline & Rt. F T & \multicolumn{2}{|l|}{$1(1.4 \%)$} \\
\hline & Rt. F T P & \multicolumn{2}{|l|}{$1(1.4 \%)$} \\
\hline & Bi F. IVT & \multicolumn{2}{|l|}{$1(1.4 \%)$} \\
\hline & IVT (Lat.) & \multicolumn{2}{|l|}{$1(1.4 \%)$} \\
\hline & Lt. F P IVT & \multicolumn{2}{|l|}{$1(1.4 \%)$} \\
\hline & Lt. O & \multicolumn{2}{|l|}{$1(1.4 \%)$} \\
\hline & Rt. T P & \multicolumn{2}{|l|}{$1(1.4 \%)$} \\
\hline & Rt. T P O IVT & \multicolumn{2}{|l|}{$1(1.4 \%)$} \\
\hline & Thalamic & \multicolumn{2}{|l|}{$1(1.4 \%)$} \\
\hline $\begin{array}{l}\text { F: Frontal. } \\
\text { T: Temporal. }\end{array}$ & $\begin{array}{l}\text { P: Parietal. } \\
\text { O: Occipital, }\end{array}$ & \multicolumn{2}{|c|}{$\begin{array}{l}\text { IVT: Intraventricular tumor. } \\
\text { Rt: Right. } \\
\text { Lt: Left. }\end{array}$} \\
\hline Table (2): H & Histopathology of $t$ & mors. & \\
\hline PNET & & & $21(30 \%)$ \\
\hline Choroid ple & exus carcinoma & & $8(11.4 \%)$ \\
\hline Anaplastic & ependymoma & & $6(8.6 \%)$ \\
\hline Pilocytic as & strocytoma G I & & $6(8.6 \%)$ \\
\hline SEGA & & & $6(8.6 \%)$ \\
\hline GBM & & & $4(5.7 \%)$ \\
\hline ATRT & & & $4(5.7 \%)$ \\
\hline Chiasmal g] & flioma (Pilocytic A & ytoma G I) & $3(4.3 \%)$ \\
\hline Desmoplast & tic Infantile Gangli & oma & $2(2.9 \%)$ \\
\hline Anaplastic : & astrocytoma G III & & $2(2.9 \%)$ \\
\hline Atypical me & eningioma & & $2(2.9 \%)$ \\
\hline Ependymob & blastoma & & $2(2.9 \%)$ \\
\hline Gangliocytc & toma & & $2(2.9 \%)$ \\
\hline Diffuse Ast & trocytoma g III & & $1(1.4 \%)$ \\
\hline Transitiona & l meningioma & & $1(1.4 \%)$ \\
\hline
\end{tabular}

PNET : Primitive neuroectodermal tumor.

G : Grade.

SEGA : Subependymal giant cell astrocytoma.

GBM : Glioblastoma multiforme.

ATRT : Atypical teratoid rhabdoid tumor.
Table (3): Complications and incidence of second surgery.

\begin{tabular}{ll}
\hline Complications: & \\
Hydrocephalus & $9(12.9 \%)$ \\
Seizure & $6(8.6 \%)$ \\
Hemiparesis & $5(7.1 \%)$ \\
Bleeding & $4(5.7 \%)$ \\
Seizure, Hemiparesis & $4(5.7 \%)$ \\
Dysphasia & $1(1.4 \%)$ \\
No complications & $41(58.6 \%)$ \\
2nd go surgery for tumor: & \\
Yes & $6(8.6 \%)$ \\
No & $64(91.4 \%)$ \\
2nd go surgery for complication: & \\
Ventriculoperitoneal shunt & $7(10 \%)$ \\
Evacuation of hematoma & $2(2.9 \%)$ \\
None & $61(87.1 \%)$ \\
\hline
\end{tabular}

\section{Discussion}

Performing Surgery on GSPBT is confronted with serious challenges. The risks for mortality and morbidity are relatively high. The wide variety in pathological entities, neurological deficits caused by the tumor, difficult circumstances during surgery owing to the vulnerability at this age and poor prognosis, are among the problems met managing these tumors [6,7]. To tackle such obstacles, tumors should be detected early based on clinical suspicion through neuroradiology, which also aids in outlining the extent of the lesion. Management is complex requiring the joined hands of efficient surgery, reliable neuroanesthesia and careful monitoring in the intensive care unit after surgery [8,9].

Surgery remains the cornerstone in management of GSPBT in children despite its risks especially when complete removal is attempted. Total removal is difficult due to the large size of these tumors, their highly vascular nature with tendency to bleed heavily and their aggressive behavior [3]. Maintenance of normal circulation should be a priority during surgery for pediatric brain tumors. Children are particularly vulnerable during surgery with liability to hypovolemia due to the smaller amount of blood in their circulation and hypothermia. Bleeding during surgery remains the most important cause for cardiac arrest in children undergoing general anesthesia [10]. We believe that there must be good communication between the surgeon and the anesthetist as conducted in the surgeries of this study. The surgeon would warn the anesthetist if there were any non-visualized bleeding. The anesthetist had packed RBCs units ready for transfusion in the operation room. Continuous assessment of blood losses in the suction and gauze was carried out. Our anesthesia team were aggressive in the 
replacement of the blood losses. However, blood transfusion has its complications including allergy, hemolytic reactions, possibility for viral infections and the risks of massive blood transfusion (e.g., electrolyte imbalance and coagulopathy [11]. These complications require the attention of the anesthetist to be picked up early. Surgery for GPSBT may last for a long duration. This increases the risk for hypothermia, which in turn encourages the bleeding through induced coagulopathy [12]. It is very important to ensure the presence of warm-air blowers and heated mattresses to keep body temperature in the normal range.

The widely used surgical technique in sizeable brain tumors is to search for a vascular pedicle and secure it. This is usually attempted in the early stages of surgery to facilitate gross total removal and control bleeding. However, in GSBT this approach is not always possible because the huge size of the tumor may hide the deep feeders and they may only be seen after debulking of the tumor. To engage in piecemeal removal of such lesions may be hazardous in children due to heavy bleeding [7]. In cortical and sub-cortical lesions of our study, we used the sub-pial technique. In this technique the tumor is attacked from the periphery in a subpial plane and the core of the lesion is dealt with at a later stage. This permits bipolar coagulation of the normal feeding vessels reaching the tumor from this plane in contrast to the abnormal vessels of the tumor which are difficult to coagulate [13] We found that this method decreased the intraoperative bleeding, which in turn helped in achieving GTR in 57 patients $(81.4 \%)$. The CUSA is a helpful tool that we used in this series. After control of bleeding, the core of the tumor was excised using the CUSA. This tool allowed for a quick efficient resection of the tumor and to decrease the operation time in these vulnerable patients. This tool is very useful when operating on tumors either with welldefined borders or not. In tumors with well-defined borders the CUSA easily debulk the center of the lesion thus facilitating the dissection and excision of the periphery by standard microsurgical methods. In tumors with poorly defined edges The CUSA can be used at a lower power at the interface between normal and abnormal tissue to distinguish between them [14].

In this study, we witnessed excessive bleeding in 2 out of 70 cases $(2.9 \%)$ requiring the termination of the procedure. These 2 cases revealed partial excision (less than 50\%) in the Postoperative control imaging. We believe that the sub-pial technique helped in avoiding this complication. Moreover, in cases of choroid plexus tumors we utilized endoscope-assisted microsurgery to help locate and secure the vascular pedicle at an earlier stage of the surgery. Surgery after embolization of the feeding vessels has been recommended by some authors. However, it is difficult in some tumors such as choroid plexus tumors [15]. Neoadjuvant chemotherapy has also been advocated as a preoperative measure to decrease tumor vascularity significantly. This method is yet associated with a reported risk of intralesional bleeding [5]. We did not use preoperative embolization or chemotherapy in our study.

\section{Conclusion:}

Surgical treatment of giant supratentorial brain tumors in children remains very challenging. A gross total resection can be achieved with a good outcome. This needs multidisciplinary team approach including good anesthesia team and proper postoperative care. Surgical techniques including sub-pial technique, endoscope-assisted microsurgery, and the CUSA may help in achieving this goal.

\section{References}

1- FAHLBUSCH R. and HOFMANN B.M.: Surgical management of giant craniopharyngiomas. Acta Neurochir (Wien) [Internet]. Dec 11; 150 (12): 1213-26, 2008 Available from: http://link.springer.com/10.1007/s00701008-0137-9.

2- ESPÍNDOLA A.A. de, MATUSHITA H., PIMENTA J.M., FERNANDES A.C. da S., ROSEMBERG S. and REED U.C.: Brain tumors in the first three years of life: A review of twenty cases. Arq Neuropsiquiatr [Internet]. Dec., 65 (4A): 960-4, 2007. Available from: http://www.ncbi.nlm. . nih.gov/pubmed/18094854.

3- de OLIVEIRA R.S., DERIGGI D.J.P., FURLANETTI L.L., SANTOS M.V., VALERA E.T., BRASSESCO M.S., et al.: The impact of surgical resection of giant supratentorial brain tumor in pediatric patients: safety and neurological outcome evaluated in 23 consecutive cases. Child's Nerv Syst [Internet]. Jan 6; 31 (1): 67-75, 2015. Available from: http://link.springer.com/10.1007/s00381-014-25834.

4- ROHRER T.R., BECK J.D., GRABENBAUER G.G., FAHLBUSCH R., BUCHFELDER M. and DÖRR H.G.: Late endocrine sequelae after radiotherapy of pediatric brain tumors are independent of tumor location. J Endocrinol Invest [Internet]. Apr., 32 (4): 294-7, 2009. Available from: http://www.ncbi.nlm.nih.gov/pubmed/19636193.

5- VAN POPPEL M., KLIMO P., DEWIRE M., SANFORD R.A., BOOP F., BRONISCER A., et al.: Resection of infantile brain tumors after neoadjuvant chemotherapy: The St. Jude experience. J. Neurosurg Pediatr [Internet]. Sep., 8 (3): 251-6, 2011. Available from: http://www.ncbi. . nlm.nih.gov/pubmed/21882915.

6- PENCALET P., SAINTE-ROSE C., LELLOUCHTUBIANA A., KALIFA C., BRUNELLE F., SGOUROS S., et al.: Papillomas and carcinomas of the choroid plexus 
in children. J. Neurosurg [Internet]. Mar., 88 (3): 521-8, 1998. Available from: http://www.ncbi.nlm.nih.gov/ pubmed/9488307.

7- KUMAR R. and SINGH S.: Childhood choroid plexus papillomas: Operative complications. Child's Nerv Syst [Internet]. Feb., 12; 21 (2): 138-43, 2005. Available from: http://link.springer.com/10.1007/s00381-004-0993-4.

8- KUN L.E.: Brain tumors. Challenges and directions. Pediatr Clin North Am [Internet]. Aug., 44 (4) :907-17, 1997. Available from: http://www.ncbi.nlm.nih.gov/ pubmed/9286291.

9- FISCHER C., PETRICCIONE M., DONZELLI M. and POTTENGER E.: Improving Care in Pediatric Neurooncology Patients: An Overview of the Unique Needs of Children With Brain Tumors. J. Child Neurol [Internet]. Mar., 31 (4): 488-505, 2016. Available from: http:// . www.ncbi.nlm.nih.gov/pubmed/26245798.

10- BHANANKER S.M., RAMAMOORTHY C., GEIDUSCHEK J.M., POSNER K.L., DOMINO K.B., HABERKERN C.M., et al.: Anesthesia-related cardiac arrest in children: update from the Pediatric Perioperative Cardiac Arrest Registry. Anesth Analg [Internet]. Aug., 105 (2): 344-50, 2007. Available from: http://www.ncbi. nlm.nih.gov/pubmed/17646488.

11- LAVOIE J.: Blood transfusion risks and alternative strategies in pediatric patients. Paediatr Anaesth [Internet]. Jan., 21 (1): 14-24, 2011. Available from: http://www.ncbi. . nlm.nih.gov/pubmed/21155923.

12- PALANISWAMY S., BENIWAL M., VENKATARAMAIAH S. and SRINIVAS D.: Perioperative management of pediatric giant supratentorial tumors: Challenges and Management strategies. J. Pediatr. Neurosci [Internet]. 14 (4): 211, 2019. Available from: http://www. pediatricneurosciences.com/text.asp?2019/14/4/211/272361.

13- HEBB A.O., YANG T. and SILBERGELD D.L.: The subpial resection technique for intrinsic tumor surgery. Surg Neurol Int. [Internet], 2: 180, 2011. Available from: http://www.ncbi.nlm.nih.gov/pubmed/22368786

14- ZEBIAN B., VERGANI F., LAVRADOR J.P., MUKHERJEE S., KITCHEN W.J., STAGNO V., et al.: Recent technological advances in pediatric brain tumor surgery. CNS Oncol [Internet]. Jan., 6 (1): 71-82, 2017. Available from: https://www.futuremedicine.com/doi/10.2217/cns2016-0022.

15- HALIASOS N., BREW S., ROBERTSON F., HAYWARD R., THOMPSON D. and CHAKRABORTY A.: Preoperative embolisation of choroid plexus tumours in children: Part I-does the reduction of perioperative blood loss affect the safety of subsequent surgery? Childs Nerv Syst [Internet]. Jan., 29 (1): 65-70, 2013. Available from: http://www.ncbi.nlm.nih.gov/pubmed/23011447.

\section{نتائج جراحات أورام المخ العملاقة فوق خيمة فئما المخيخ فى الأطفال :

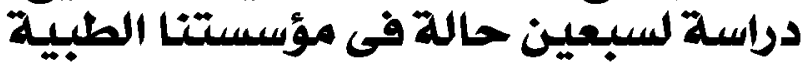

$$
\begin{aligned}
& \text { تعد جراحات أورام المخ العملاقة فوق خيمة المخيخ فى الأطفال تحدياً كبيراً. قد يصعب تشخيص هذه الأودام بسبب أعراضها غير المحددة. } \\
& \text { تعد جراحات هذه الأودام خطيرة بسبب الميل إلى النزيف الحاد والثديد وهو أمر خطير فى هذه الفئة العمرية. } \\
& \text { في هذه الدراسة نقوم بتقييم تجريتا الجراحية مع هذه الأودام من حيث نسبة استئصال الوم ونتائج الجراحة. }
\end{aligned}
$$

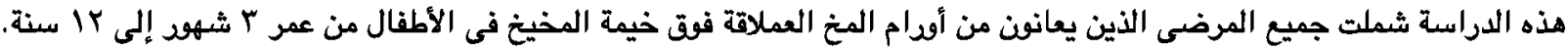

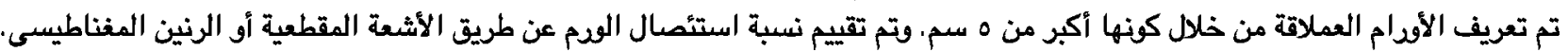

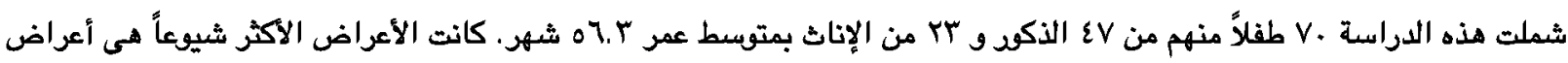

$$
\begin{aligned}
& \text { ارتفاع ضعغط المـخ في الهذه } 71 \text { حالة. }
\end{aligned}
$$

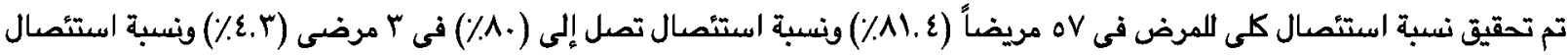

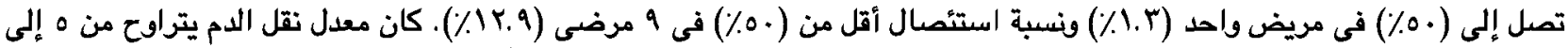

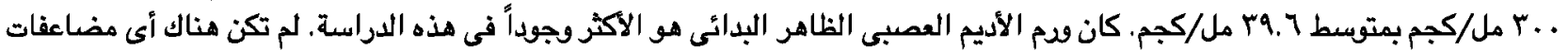

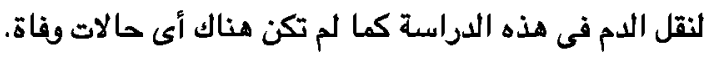

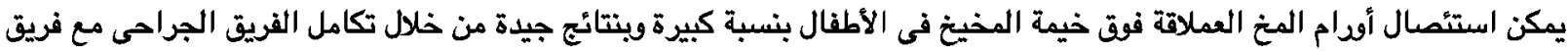

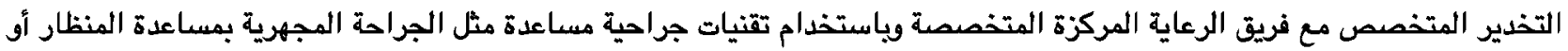

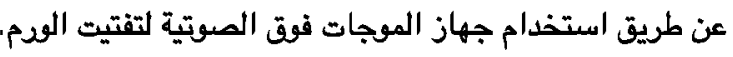

